\title{
Influence of Food-Deprived Chicken Serum on Protein Synthesis of Chicken Embryo Fibroblasts
}

\author{
Kazumi Kita, Miki Miyazaki and Jun-ichi Okumura \\ School of Agricultural Sciences, Nagoya University, Nagoya 464-01, Japan
}

\begin{abstract}
We have examined the influence of food-deprivation on the activity of chicken serum to stimulate protein synthesis of chicken embryo fibroblast (CEF). Chicken serum, whose activity to synthesize protein was compared with that of fetal calf serum (FCS), was collected from 6-week-old chickens food-deprived or allowed free access to a commercial diet for 2 days. CEF was derived from 9 -day-old chicken embryos. The concentrations of serum were varied at $0,2,5,10$ and $20 \%(\mathrm{v} / \mathrm{v})$ in the culture medium. After incubating for $54 \mathrm{~h}$, protein synthesis was measured by the incorporation of L-[2, 6 $\left.{ }^{3} \mathrm{H}\right]$ phenylalanine from medium into protein during further $18 \mathrm{~h}$. The lowest value for protein synthesis was observed in CEF cultured in absence of serum. Even if any types of serum were supplemented in the culture medium, protein synthesis increased with rising serum concentrations from 2 to $20 \%$. When the serum concentration was above $10 \%$, protein synthesis of CEF cultured with food-deprived chicken serum was significantly lower than those in other treatments. There was no significant difference in protein synthesis between well-fed chicken serum and food-deprived chicken serum supplemented with recombinant chicken insulin-like growth factor-I (IGF-I) at $50 \mu \mathrm{g} / \mathrm{m} l$. It was concluded that the reduced protein synthesis of $\mathrm{CEF}$ cultured with food-deprived chicken serum was, in part, because the decrease in blood concentration of IGF-I.
\end{abstract}

(Jpn. Poult. Sci. 33 : 339-346, 1996)

Key words : chicken embryo fibroblast, protein synthesis, food-deprivation, serum, insulin-like growth factor-I

\section{Introduction}

One of the most important factors which influence the rate of protein synthesis in the whole-body and various tissues is the alteration of nutritional conditions. When dietary protein intakes decreased from the requirement level to deficiency, the rate of protein synthesis in the whole-body (KiтA et al., 1993 ; Muramatsu et al., 1987) and livers of young chickens (KITA et al., 1996 a) also decreased, whereas excess protein intakes similarly decreased whole-body and liver protein synthesis (KITA et al., 1989, 1996 a ; Kita and OKumura, 1993). Liver protein synthesis of chickens was decreased by food deprivation, which is one of the severest malnutrition and was thereafter recovered markedly by refeeding (KITA et al., 1996 a).

It has been established that the supplementation of animal serum into the culture medium is required to culture mammalian and avian cells in vitro. Recently, TREISMAN (1985) has demonstrated the existence of a short DNA sequence element, the serum 
response element (SRE), which locates at a region of the 5'-franking sequence of the proto-oncogene $c$-fos. Thereafter, TREISMAN (1987) purified and identified a novel polypeptide, serum response factor, which binds to SRE to mediate transient transcriptional activation of $c$-fos gene in response to serum. One of the reason why animal serum is required has been shown that a large number of growth factors, which are necessary to induce cell growth and development, exist in the serum. Some growth factors in the serum like insulin-like growth factor-I (IGF-I), which has been known as a mediator of growth hormone to stimulate protein synthesis, cell growth and development etc, are associated with the change in nutritional conditions (KiTA et al., $1996 \mathrm{~b}$ ). However, the influence of changes in nutritional conditions on the serum activity to induce cell proliferation has not been clarified. Therefore, in the present study, we examined the influence of food deprivation on the activity of chicken serum to stimulate protein synthesis of chicken embryo fibroblasts (CEF).

\section{Materials and Methods}

Twenty single-comb White Leghorn male chickens from a local hatchery (Hattori Yokeien Ltd, Nagoya) were maintained on a commercial chick starter (crude protein $215 \mathrm{~g} / \mathrm{kg}$, metabolizable energy $12.1 \mathrm{~kJ} / \mathrm{g}$; Marubeni Siryou Ltd, Tokyo) from hatching until 6 weeks of age. The birds were maintained in a temperature-controlled $\left(29 \pm 1^{\circ} \mathrm{C}\right)$ room, and continuous illumination was provided. At this age, chickens were divided evenly into 2 groups of 10 chickens each. Ten chickens in a group were food-deprived for 2 days and remained 10 chickens were allowed free access to the diet. After 2 days of food-deprivation, chickens were anesthetized by a injection of pentobarbital and blood was collected from the wing vein. After centrifuge at $3,000 \times \mathrm{g}$ for $10 \mathrm{~min}$ at $4^{\circ} \mathrm{C}$, serum was collected from whole blood and stored at $-20^{\circ} \mathrm{C}$ until cell culture.

Ten fertilized eggs maintained in our laboratory were incubated for 9 days. At this time six embryos were taken from eggs, decapitated, rinsed in Dulbecco's phosphate buffered saline (PBS) $\left(+\mathrm{Ca}^{2+},+\mathrm{Mg}^{2+}\right.$ ) including $0.25 \mathrm{mg} / \mathrm{ml}$ fungizone (Gibco Laboratories Life Technologies Inc., NY) and $50 \mu \mathrm{g} / \mathrm{ml}$ gentamycin (Wako Pure Chemical Industries, Ltd., Osaka). After removing wings and feet, embryos were eviscerated, rinsed in PBS $\left(+\mathrm{Ca}^{2+},+\mathrm{Mg}^{2+}\right)$ including fungizone and gentamycin and then minced finely with scissors. The minced tissues were mixed with $15 \mathrm{ml}$ of PBS including $0.25 \%(\mathrm{w} / \mathrm{v})$ trypsin (Trypsin $1: 250$, Difco Laboratories, MI) and $0.025 \%(\mathrm{w} /$ v) EDTA, and incubated at $37^{\circ} \mathrm{C}$ for $15 \mathrm{~min}$. After centrifuge $(500 \times \mathrm{g}, 1 \mathrm{~min})$, the supernatant was taken and mixed with $15 \mathrm{~m} l$ of Dulbecco's modified Eagle's medium (DMEM, Sigma Chemical Company, MO) including 10\% (w/v) tryptose phosphate broth (TPB, Difco Laboratories, MI) and $5 \%(\mathrm{v} / \mathrm{v})$ fetal calf serum (FCS, Gibco Laboratories Life Technologies Inc., NY). The cells were settled down by centrifuge for $5 \mathrm{~min}$ at $1,000 \times \mathrm{g}$, and then the supernatant was removed. After rinsing cell pellet with DMEM including 10\% TPB and 5\% FCS, the cells were resuspended in $20 \mathrm{~m} l$ of DMEM with $10 \% \mathrm{FCS}$, and then seeded in a $80 \mathrm{~m} l$ flask at $3 \times 10^{7}$ cells, and incubated at $37^{\circ} \mathrm{C}$ in $5 \% \mathrm{CO}_{2} / 95 \%$ air $(\mathrm{v} / \mathrm{v})$. Approximately after $1 \mathrm{~h}$ of seeding cells, the medium was changed. Just before cells were confluent, attached cells were resuspended in 
PBS including $0.25 \%$ trypsin and $0.025 \%$ EDTA. The suspended cells were seeded into $24-$ well plate with $1 \times 10^{7}$ cells/well $\left(2 \mathrm{~cm}^{2}\right)$, and incubated in DMEM with $10 \% \mathrm{FCS}$ at $37^{\circ} \mathrm{C}$. When $\mathrm{CEF}$ expanded to approximate $50 \%$ of a well, the effect of serum on protein synthesis was examined.

Two experiments were conducted. Firstly, the influence of fasting on the activity of chicken serum to stimulate protein synthesis of CEF was examined. When CEF occupied approximately $50 \%$ of a well, the medium was drawn off from the well. CEF was rinsed with DMEM without FCS twice and then incubated in DMEM excluding FCS under $5 \% \mathrm{CO}_{2} / 95 \%$ air atmosphere at $37^{\circ} \mathrm{C}$. After $2 \mathrm{~h}$ of incubation, the medium was removed and added DMEM including either FCS or chicken serum collected from food-deprived or well-fed chickens. The concentration of serum in the medium was varied at $0,2,5,10$ and $20 \%$. After incubating for $54 \mathrm{~h}$, in the meantime the medium was replaced by new one at $48 \mathrm{~h}$ of incubation, $\mathrm{L}-\left[2,6^{-}{ }^{3} \mathrm{H}\right]$ phenylalanine $(2.11 \mathrm{TBq} / \mathrm{m}$ $\mathrm{mol}, 37 \mathrm{MBq} / \mathrm{ml}$, Amersham Life Science, Ltd., Tokyo) was added into the medium, in which the radioactivity was $37 \mathrm{kBq} / \mathrm{ml}$. Thereafter, CEF was incubated for further 18 h. At $72 \mathrm{~h}$ of incubation, the medium was drawn away and cells were rinsed with icecold PBS $\left(+\mathrm{Ca}^{2+},+\mathrm{Mg}^{2+}\right)$ twice. The intracellular free amino acids were removed by rinsing with ice-cold $5 \%(\mathrm{w} / \mathrm{v})$ trichloroacetic acid twice. After rinsing with ice-cold water, $1 \mathrm{~m} l$ of $0.5 \mathrm{M} \mathrm{NaOH} / 0.1 \%$ Triton $\mathrm{X}-100$ was added and incubated at room temperature for $30 \mathrm{~min}$. After dissolving protein by pipetting, the radioactivity in $\mathrm{NaOH} /$ Triton $\mathrm{X}-100$ solution was measured using a scintillation counter as an index of protein synthesis.

In the second experiment, the influence of recombinant chicken IGF-I supplemented into food-deprived chicken serum on protein synthesis of CEF was examined. All procedures except for the serum in the culture medium were described previously for Experiment 1. Four experimental groups were prepared. CEF in three experimental groups was cultured with $20 \%$ of food-deprived chicken serum and the remaining group was cultured with $20 \%$ of well-fed chicken serum as reference. Recombinant chicken IGF-I (GroPep Ltd. Adelaide, South Australia) was added into culture medium of two groups of food-deprived chicken serum at final concentrations of 10 and $50 \mu \mathrm{g} / \mathrm{ml}$.

Statistical analysis of data was performed by two-way ANOVA (Cochran and Cox, 1992) followed by a protected LSD to assess the difference between means using the General Linear Model procedures of SAS (1985).

\section{Results}

Fig. 1 shows CEF cultured in DMEM including food-deprived chicken serum. In absence of serum CEF hardly grew up during $72 \mathrm{~h}$ (Fig. $1 \mathrm{a}$ ). The lowest concentration $(2 \%)$ of food-deprived chicken serum did not stimulate cell growth (Fig. 1 b). However, above this level, CEF proliferated rapidly along with an increase in serum concentration from 5 to $20 \%$ (Fig. $1 \mathrm{c}-1 \mathrm{e}$ ). The cell proliferation activity of FCS and well-fed chicken serum looked similar to that of food-deprived chicken serum (data not shown).

The serum activity to stimulate protein synthesis of CEF is shown in Fig. 2. In 

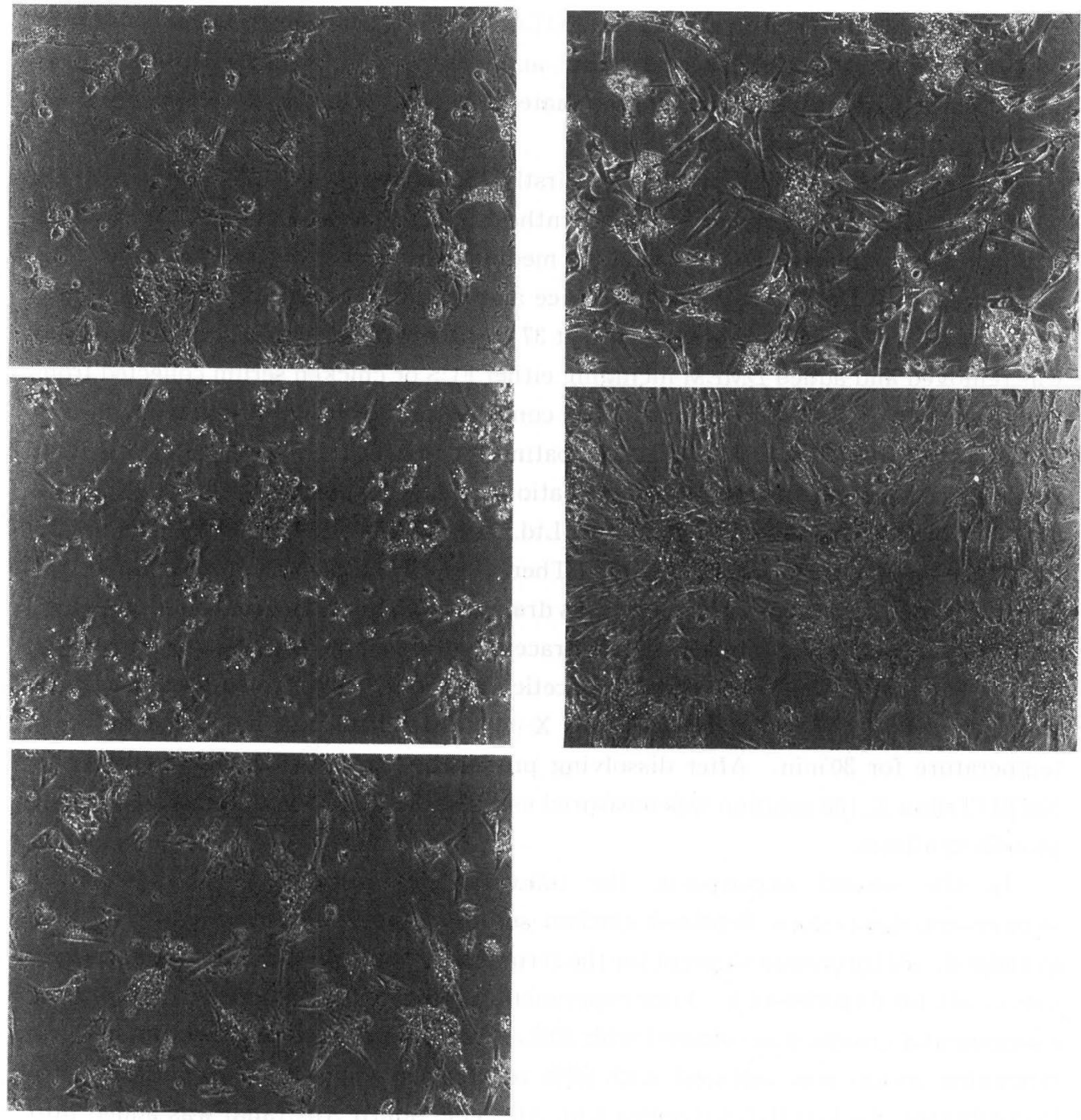

Fig. 1. Chicken embryo fibroblasts cultured in Dulbecco's modified Eagle's medium with 0 (1 a), $2(1 \mathrm{~b}), 5(1 \mathrm{c}), 10(1 \mathrm{~d})$ and $20 \%(1 \mathrm{e})(\mathrm{v} / \mathrm{v})$ of food-deprived chicken serum at for $72 \mathrm{~h}$. Magnification was $\times 200$.

absence of serum the lowest value for protein synthesis was observed. Regardless of the difference in animal species, when serum was supplemented in the medium at $2 \%$, protein synthesis seemed to be stimulated, but not significantly. Moreover, protein synthesis of CEF was increased significantly by elevating serum concentration from $2 \%$ to $20 \%(\mathrm{P}<0.05)$. When the serum concentration was above $10 \%$, protein synthesis of $\mathrm{CEF}$ cultured with food-deprived chicken serum was significantly lower than those of other treatments $(\mathrm{P}<0.05)$.

The effect of recombinant chicken IGF-I supplemented into food-deprived chicken serum on protein synthesis of CEF is shown in Fig. 3. Protein synthesis of CEF cultured with food-deprived chicken serum was significantly lower than that with 


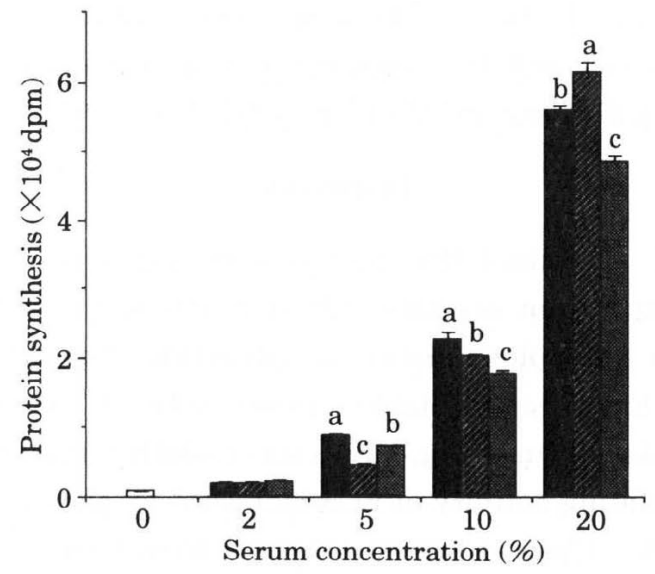

Fig. 2. Protein synthesis of chicken embryo fibroblasts cultured in Dulbecco's modified Eagle's medium including fetal calf serum ( ), well-fed chicken serum ( ) and fooddeprived chicken serum ( $)$. The concentrations of serum were at $0,2,5,10$ and $20 \%(\mathrm{v} / \mathrm{v})$. After $54 \mathrm{~h}$ of cell culture, the incorporation of $\mathrm{L}-\left[2,6^{-3} \mathrm{H}\right]$ phenylalanine was measured for further $18 \mathrm{~h}$ as an index of protein synthesis. Means not sharing a common superscript at the serum concentration are significantly different at $\mathrm{P}<$ 0.05 .

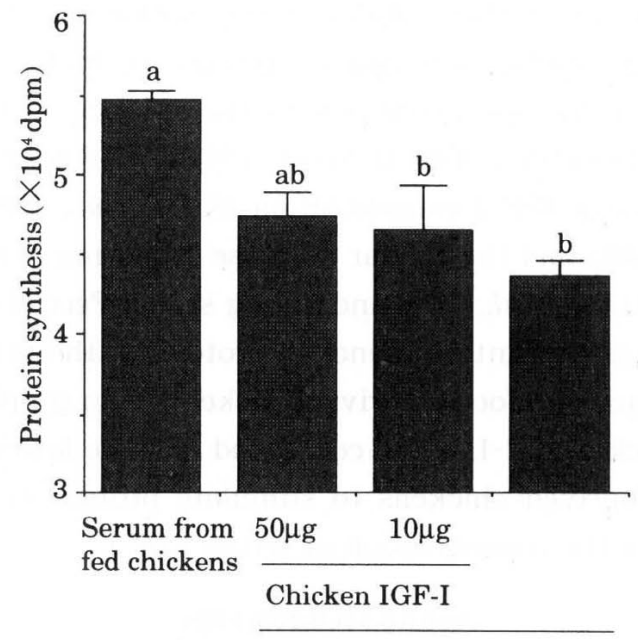

Serum from fasted chickens

Fig. 3. Influence of recombinant chicken IGF-I supplemented into food-deprived chicken serum on protein synthesis of chicken embryo fibroblasts. The concentration of wellfed and food-deprived chicken serum in the medium was $20 \%$. After $54 \mathrm{~h}$ of cell culture, the incorporation of $\mathrm{L}-[2$, $\left.6^{-3} \mathrm{H}\right]$ phenylalanine was measured for further $18 \mathrm{~h}$ as an index of protein synthesis. Means not sharing a common superscript at the serum concentration are significantly different at $\mathrm{P}<0.05$. 
well-fed chicken serum $(\mathrm{P}<0.05)$. There was no significant difference in protein synthesis of CEF between well-fed chicken serum group and food-deprived chicken serum supplemented with $50 \mu \mathrm{g} / \mathrm{m} l$ of chicken IGF-I $(\mathrm{P}<0.05)$.

\section{Discussion}

It has been well recognized that mammalian and avian cells cultured in vitro require serum collected from animals and that the serum activity to induce cell proliferation is due to a complex balance of interaction of growth factors. Although many types of serum have been available commercially, FCS has been widely used for in vitro cell culture. As shown in Fig. 2, FCS successfully stimulated protein synthesis of $\mathrm{CEF}$, and the stimulating activity of FCS increased by elevating the serum concentration from 2 to $20 \%$. Chicken serum obtained from well-fed chickens had equal potency to induce protein synthesis of $\mathrm{CEF}$ compared to FCS.

In the present study, the influence of food-deprivation on protein synthesis of $\mathrm{CEF}$ was also examined. When the serum concentration was above $10 \%$ in the medium, protein synthesis of CEF cultured with food-deprived chicken serum was significantly lower than those of other treatments. It has been established that in avian serum as well as mammalian serum there are a number of growth factors of which concentration easily alters in response to the change in nutritional condition. Chicken IGF-I has been characterized and shown to be 70 amino acid polypeptides (BALLARD et al. 1990) and it has been reported that plasma IGF-I concentration was responsive to the change in nutritional conditions (KITA et al., 1996b). Some findings pointing out an important role for IGF-I in the control of growth and metabolism in chickens have been reported. When exogenous IGF-I was administrated to the chicken embryo, its growth and differentiation were stimulated (GIRBAU et al., 1987). Furthermore, food-restriction markedly reduced plasma IGF-I concentration (KITA et al., $1996 \mathrm{~b}$; MoRishita et al., 1993 ; BALLARD et al., 1990), and the similar decrease in plasma IGF-I was also found in prepubertal pigs (ChARLton et al., 1993) and young sheep (Pell et al., 1993). As shown in Fig. 3, there was no significant difference in protein synthesis of CEF between well -fed chicken serum group and food-deprived chicken serum supplemented with $50 \mu \mathrm{g} /$ $\mathrm{m} l$ of recombinant chicken IGF-I. This concluded that the lowered activity of serum collected from food-deprived chickens to stimulate protein synthesis was, in part, because the decrease in the concentration of serum IGF-I.

\section{Acknowledgements}

Financial support was provided by a Grant-in-Aid (Number 07760263) for Encouragement of Young Scientists from the Ministry of Education, Science and Culture, Japan. This study was presented at the XX World's Poultry Congress in New Delhi, India on September 1996 with the financial support of the Japan Poultry Science Association.

\section{References}

Ballard, F.J., R.J. Johnson, P.C. Owens, G.L. Francis, F.Z. Upton, J.R. McMurtry and J. 
C. Wallace (1990) Chicken insulin-like growth factor-I : Amino acid sequence, radioimmunoassay, and plasma levels between strains and during growth. General and Comparative Endocrinology, 79 : 459-468.

Charlton, S.T., J.R. Cosgrove, D.R. Glimm and G.R. Foxcroft (1993) Ovarian and hepatic insulin-like growth factor-I gene expression and associated metabolic responses in prepubertal gilts subjected to feed restriction and refeeding. Journal of Endocrinology, 139 : 143-152.

Cochran, W.G. and G.M. Cox. (1992) Factorial experiments with main effects confounded : Split-plot designs. In 'Experimental Designs. 2nd edition'. pp 293-316. John Wiley \& Sons, Inc. New York.

Girbau, M., J.A. Gomez, M.A. Lesniak and F. De Pablo (1987) Insulin and IGF-I both stimulate metabolism and growth in the postneurula chick embryo. Endocrinology, $121: 1477-1482$.

Kita, K., S. Matsunami and J. Okumura (1996a) The relationship of protein synthesis to mRNA levels in the liver of chicks under various nutritional conditions. Journal of Nutrition, $126: 1610-1617$.

Kita, K., T. Muramatsu and J. Okumura (1993) Effect of dietary protein and energy intakes on whole-body protein turnover and its contribution to heat production in chicks. British Journal of Nutrition, 69 : 681-688.

Kita, K., T. Muramatsu J. Okumura (1989) Influence of excess protein intake on wholebody protein synthesis in chicks. Nutrition Report International, 39 : 1091-1097.

KITA, K. and J. Okumura (1993) Protein synthesis in liver and breast muscle of chicks fed a high protein diet. British Poultry Science, $34: 553-558$.

Kita, K., F.M. Tomas, P.C. Owens, S.E. Knowles, B.E. Forbes, Z. Upton, R. Hughes and F. J. BALLARD (1996 b) Influence of nutrition on hepatic insulin-like growth factor-I (IGF-I) mRNA level and plasma concentration of IGF-I and IGF-II in meat-type chickens. Journal of Endocrinology, 149 : 181-190.

Morishita, D., K. Sasaki, M. W AKita and S. Hoshino (1993 a) Effect of fasting on serum insulin-like growth factor-I (IGF-I) levels and IGF-I binding activity in cockerels. Journal of Endocrinology, 139, 363-370.

Muramatsu, T., K. Kita, I. Tasaki and J. Okumura (1987) Influence of dietary protein intake on whole-body protein turnover in chicks. British Poultry Science, $28: 471$ 482.

Pell, J.M., J.C. SAunders and R.S. Gilmour (1993) Differential regulation of transcription initiation from insulin-like growth factor-I (IGF-I) leader exons and of tissue IGFI expression in response to changed growth hormone and nutritional status in sheep. Endocrinology, 132: 1797-1807.

SAS Institute Inc. (1985) SAS ${ }^{\circledR}$ User's Guide : Statistics. Version 5 Edition, SAS Institute Inc., Cary, NC.

TREISman, R. (1985) Transient accumulation of c-fos RNA following serum stimulation requires a conserved 5' element and c-fos 3' sequences. Cell, $42: 889-902$.

TREISman, R. (1987) Identification and purification of a polypeptide that binds to the cfos serum response element. EMBO Journal, 6 : 2711-2717. 


\title{
絶食したニワトリから得た血清がニワトリ肧繊維芽細胞の 蛋白質合成におよぼす影響
}

\author{
喜多一美・宮崎美糺・奥村純市
}

名古屋大学農学部, 名古屋市 464-01

絶食したニワトリから得た血清が，ニワトリ肧繊維芽 細胞の蛋刍質合成におよぼす影響について調査した。2 日間市販通常飼料を自由攝取あるいは 2 日間絶食させた 6 週齢のニワトリから血清を採取し，ニワトリ肧繊維芽 細胞の蛋白質合成促進効果をウシ胎児I血清と比較した。 ニワトリ肧繊維芽細胞は，9月間搫卵したニワトリ胚か ら採集した。培養液中の向清濃度は $0,2,5,10$ および $20 \%$ とした。各濃度の血清を添加した培養液中でニワト リ肧繊維芽細胞を 54 時間培養した後, L- $\left[2,6-{ }^{-3} \mathrm{H}\right]$ フェ ニルアラニン $(37 \mathrm{kBq} / \mathrm{m} l)$ を培養液中に添加し, さら に 18 時間培養し，蛋白質に取り込まれた放射能量を蛋 刍質合成の指標とした。

無伹清培養液群の蛋白質合成が最む低くなり，全ての 種類の血清において，血清濃度が 2 から $20 \%$ と上昇す るのにとあなって蛋白質合成が増加した。血清濃度が
10\%以上では, 絶食したニワトリから得た租清を用いて 培養した繊維芽細胞の蛋毛質合成は，他の群の蛋㫐質合 成より有意に低かった。絶食したニワトリから得だ向清 群（片清濃度 20\%）の培養液にニワトリインシュリン様 増殖因子-I（IGF-I）を $50 \mu \mathrm{g} / \mathrm{m} l$ となるように添加した ところ, ニワトリ胚繊維芽細胞の蛋白質合成は, 通常飼 料を自由掑取させたニワトリの们清群との間に有意な差 は羿められなかった。

以上の結果から，ニワトリ血清のもつニワトリ肧繊維 芽細胞の蛋白質合成促進效果の一部は, 向中 IGF-I に よって説明できることが示された。

（家禽会訫，33：339-346, 1996） キーワード：ニワトリ胚緎維芽細胞, 蛋白質命成, 絶食, III清, インシュリン様増殖因子-I 